\title{
Protection of Human Rights from the Police-Position in Regional Systems
}

\author{
H. Abdul Azeez
}

\begin{abstract}
The measures that are being taken by the Countries to prevent the violation of human rights by the policedifferwidely in its effectiveness. The disparity among the nations accentuate for super national bodies on regional basis for the effective protection of human rights from the police. There exist European, Inter-American, African, Minsk and Arab regional systems for the protection of Human rights on super national basis. Regional systems also differ in protecting the human rights from the police mainly due to the socio-economic and cultural diversities that exist in the regions. This article analyses how effective is the regional mechanisms in protecting human rights from the police.
\end{abstract}

Index Terms-Human rights, police, unlawful arrest/detention, human rights conventions.

\section{INTRODUCTION}

When domestic institutions fail to protect human rightsit may become necessary to seek redress beyond national boundaries. Regional legal frameworks offerthe victim of violations of human rights in a nation a chance to bring his case before a regional body. The known regional systems that is operative for the protection of human rights are the European, Inter-American and African systems. Some countries such as former Soviet Russian member countries which are not part of Coucil of Europe, Arab countries in the Middle East and South Asian Countrieswhich do not have an effective mechanism to check the violation of human rights on international basisnow emerges with a system of regional mechanism for the protection of human rights within their region. The protection of the human rights in European, American, African, Arab and Asian countries are not uniform due to factors such as the difference in economic and ideological diversity that determines the status of nations as developed or developing, democratic orsocialist, and also the diverse religions that is adopted as State religion in many countries within the regions e.g. Saudi Arabia, Qatar, Iran. A detailed analysis is made on how the mechanism on the human rights protection from the police works in the regional systems.

\section{EUROPEAN SYSTEM}

When League of Nations was formed, the human rights issues were not looked into seriously due to which there were large numbers of human rights violations by nations which ended up in Second World War. As both the world conflicts

Manuscript received October 7, 2012; revised November 27, 2012.

H Abdul Azeez is with the Head of Department (Law), Police Academy, Thrissur, Kerala, India (e-mail:azeezhma@gmail.com). originated in Europe, many European States believed that in addition to the United Nations Organization, there had to be a specific European regional response concentrating on human rights. As a result, Europe developed different documents in order to protect human rights. The principal document that relates with human rights' protection specially in relation to civil and political rights is the European Convention on Human Rights and Fundamental Freedoms, 1950 or shortly, the European Convention on Human Rights (ECHR).It is a regional treaty by which the Member States of the Council of Europe $(\mathrm{CoE})$ promise to secure fundamental civil and political rights to everyone within their jurisdiction. In fact, the emphasis of the Convention is on individual civil and political rights rather than collective economic, social and cultural rights.

The ECHR provides specific protection for the right to life (Art.1), liberty and security of person (Art.5), freedom from unlawful arrest and detention(Art.5) and right against torture and inhuman treatment(Art.3). These rights are categorized as absolute and Art.15 provides that these rights cannot be derogated even during national emergency. Art. 5 of the Convention is specifically significant as it provides protection from arbitrary arrest and detention by the police. Art.5 (2) provides that in the event of arrest, the arrested person shall be informed of the reasons for the arrest and any charges against him promptly in a language understood by him/her. Art.5 (3) directs that the arrested person shall be brought before a judicial officer. A remedy is also provided in Article 5(5) which sets out that in the event of arbitrary arrest or detention, the victim has an enforceable right to compensation. Thus, Article 5 protects persons from arbitrary arrest and detention and also provides a right to claim compensation in the event of unlawful encroachment to liberty.

The enforceable mechanism under the Convention is noteworthy. Any person whose human right has been violated and has not been satisfied by the decision of the national tribunal can directly approach the European Court of Human Rights(ECtHR) which is established in 1998 as per Protocol 11 of the ECHR. The ECtHR has jurisdiction over Member States of the CoE which has opted to accept the jurisdiction of the Court. Once a State has accepted the jurisdiction, all the decisions of the ECtHR in connection with the State are binding on it. Besides individual application, the ECtHR accepts applications relating to human rights violations from States as well. However, it is rare for a State to submit allegations against another State, unless the violation is severe. Art. 26 of ECHR makes it clear that the individual applicant must not be anonymous and all domestic remedies available to the applicant must have been exhausted before making an application to the ECtHR. The 
issue must relate to a violation of a right set forth in the Convention. The Committee of Ministers (CoM) [1] of the CoE monitors that the decisions of the ECtHR are complied with by the Member States [2]. The mechanism for the effective protection of human rights through a super national ECtHR and the monitoring by the CoM make the European regional system distinctive for the protection of the human rights form the police.

Besides the ECHR, there is the European Convention for the Prevention of Torture and Inhuman or Degrading Treatment or Punishment, 1987 or shortly, Convention against Torture (CAT) [3]. The main purpose of the Convention is to provide effective remedy from police action and State brutality within the CoE. The CAT creates a separate Committee for the prevention of torture to monitor and supervise the implementation of the provisions of the CAT within the Member States [4]. The Committee has authority to visit a Member State where it believes that a person's liberty has been violated [5]. When such intention is expressed by the Committee it becomes obligation on the State Party to provide facilities and access to visit such places. The Committee may interview persons deprived of their liberty in private and may communicate freely with any person whom it believes can supply relevant information [6]. Although the Committee has no judicial authority, yet it can report to the Committee of Ministers of $\mathrm{CoE}$ regarding its findings after the visit to a country.

\section{THE INTER-AMERICAN SYSTEM}

The Inter-American regional system operates among the Member countries of the American continent. The Organization of American States [7] constituted the Inter-American Commission on Human rights in 1959. The Commission thought it necessary to adopt a Convention for American States in tune with the American Declaration of the Rights and Duties of Man, 1948 for the effective protection of human rights in the region with a suitable mechanism for supervision and enforcement. This idea has paved the way for the adoption of American Convention on Human Rights in 1969 (ACHR).In fact, the Commission was behind making the ACHR and it came into force in 1978[8]. The ACHR guarantees right to life (Art.4), liberty (Art.7), human treatment in custody (Art.5), judicial protection(Art.25), etc. It provides for the reconstitution of Inter-American Commission on Human Rights and the Inter-American Court of Human Rights. The Commission makes recommendations to the Governments of the Member States for the adoption of measures in favor of protection of human rights within the framework of their domestic law and constitutional provisions. The Commission has authority to take action on petitions and other communications pursuant to its authority under the provisions of Articles 44 through 51 of the ACHR. Article 44 makes it clear that any person or group of persons, or any non-governmental entity legally recognized in one or more Member States of the Organization, may lodge petitions with the Commission. Thus, a single individual can file a complaint against the State which has violated or failed to take appropriate action against the violation of human rights.
Article 52 provides for the constitution of a 7 Judge Inter-American Court of Human Rights. The Commission shall appear in all cases before the Court [9]. It is provided under Article 61 that only the States Parties and the Commission shall have the right to submit a case before the Court. An individual or groups cannot have direct access to the Court. It is only through the Commission that their cases can be brought before the Court. If the Court finds that there has been violation of a right protected by the ACHR, the Court has authority to rule that the injured party be ensured the enjoyment of his right that was violated, and if appropriate, it shall order for fair compensation to be paid to the injured party [10].

The Inter-American Convention on the Forced Disappearance of Persons, 1994 was made due to the forced disappearances and abuse of human rights that were widespread in Latin and South America for much of the twentieth century. The police and other law enforcement officials within many National States played a vital role in the forced disappearance cases. The Convention makes it clear that forced disappearance could not be treated as political offences [11], nor can anybody take the defense of 'superior orders' and the criminal prosecutions would not be subject to statutes of limitation [11]. Convention is categorical in stating that war, threats of political instability, or other public emergencies would also not justify the crime of disappearance of persons [11], and detainees should be held in an officially recognized place of detention [11]. Convention casts a duty on the State Parties to establish and maintain official up-to-date registries of the detainees and to make them available to relatives, judges, attorneys or any other person having a legitimate interest in the detainee [11]. Complaint regarding the alleged forced disappearance shall be made to the Inter-American Commission on Human Rights. Many cases of forced disappearances occur due to political rivalry and it occurs with the aid of police or other law enforcement machineries and hence, State Government may suppress such issues. The Inter- American regional settings provides fairly good procedure in the event of forced disappearances to bring the matter before the Inter-American Commission on Human rights.

However, it is worth noting that in the case of European system the individuals have direct access to the European Court of Human Rights where as in the Inter-American system the individuals or groups do not have direct access to the Court. Besides, in the European system there is Committee of Ministers to monitor that the decisions of the ECtHR are being complied with by the Member States. In the Inter-American system such mechanism is not available. Hence, it must be considered that the Inter-American system is weaker than the European system in its scope and enforceability.

\section{AFRICAN REGIONAL SYSTEM}

The regional system for Africa is based on the African Charter on Human and Peoples' Rights, 1981 (ACHPR), shortly known as the "African Charter", which entered into force in 1986. Article 4 of the African Charter guarantees right to life and it prohibit arbitrary deprivation of life. 
Article 5 provides for the respect of the inherent dignity of human beings and prohibits all forms of torture, cruel, inhuman or degrading punishment and treatment. Article 6 provides the right to liberty and the security of person and it further guarantees that no one may be deprived of his freedom except for reasons and conditions previously laid down by law. In particular, it provides no person may be arbitrarily arrested, detained or tortured. Article 7 guarantees a right to an appeal to competent national organs against acts of violation of fundamental rights. These are the important safeguards that the Charter provides from arbitrary arrest, illegal detention, torture, etc.

Regarding the enforceability, the African Charter provides for the constitution of eleven members African Commission on Human and Peoples' Rights (African Commission) [16]. In addition to the African Commission there is the African Court of Justice and Human Rights created in 2008. However, the Court is not operational yet. So the only enforceable mechanism available is through African Commission.

The main function of the African Commission is to ensure protection of human and peoples' rights within the region [17]. Though the Charter provide for two mechanisms for the enforceability of the rights, namely, inter-state communications and communication from other sources, the Charter does not specifically provide that individuals can make complaints to the Commission. However, the Charter provides for fulfilling certain criteria before submitting communications such as (i) the communication must indicate the author (ii) it must be submitted only after all domestic remedies have been exhausted "unless it is obvious that this procedure is unduly prolonged", etc. These criteria points towards making individual communications acceptable to the Commission. The authority available to the Commission is only to resort to amicable settlement. Thus, the Commission is very weak in enforcing its decisions.

Thus, the African regional system is functionally not effective in protecting the human rights from being violated by the police in the region. The Member States are not committed to comply with the recommendations of the African Commission. Hence, the African human rights protection mechanism requires much work and task to make the enforceability of human rights more effective.

\section{The Minsk Convention}

The Commonwealth of Independent States Convention on Human Rights 1995, shortly "the Minsk Convention", is an association of those former Soviet Union States such as Belarus, Georgia, Kyrgyzstan, Moldova, Russia, Tajikistan, etc., which cannot become Members of the $\mathrm{CoE}$ as they are outside the European territory. Hence, these States rightly decided to have a separate Convention for the protection of human rights within their region and as a result the Minsk Convention came into existence. The Convention guarantees right to life [18], liberty and security of person [19], and prohibits torture and cruel, inhuman or degrading treatment[20]. It provides that anyone who is arrested shall be informed of the reasons for his arrest at the time of his arrest and in a language which is understood by him [21]. Everyone who is deprived of his liberty by arrest or detention shall be entitled to have the lawfulness of his arrest or detention examined by a court (Art. 5(3)). It also provides that any person who is deprived of his liberty shall be entitled to humane treatment and to respect for his dignity as a human being (Art. 5(4)). Persons who have been subjected to unlawful arrest or detention shall be entitled to compensation in accordance with national legislation for the damage caused (Art.5).

The Convention elaborately provides provisions for protection from arbitrary arrest, illegal detention, torture or other inhuman treatment, etc.It also elaborates the procedure while making arrest or detention of a person. However, the enforceable mechanism is very weak. As per the provisions of the Convention, a Human Rights Commission of the Commonwealth of Independent States is in existence. Nevertheless, the Commission is functionally at its marginal level since the system itself is newly emerging under diverse circumstances. However, the Commission monitors practices of the States by issuing recommendations.

\section{ARAB Regional System}

The Arab regional system works for the protection of human rights in Muslim countries in the Middle Eastern region. The protection system is mainly based on the Arab Charter on Human Rights, 2004. However, before the Charter of 2004, there were attempts to have a protection system in the region. The first document in this regard was the Cairo Declaration on Human Rights, 1990 (the Cairo Declaration). Article 20 of the Cairo Declaration proclaims that it is not permitted without legitimate reason to arrest an individual, or restrict his freedom, to exile or to punish him. It further prohibits from physical or psychological torture or to any form of maltreatment, cruelty or indignity. All rights and freedoms stipulated in the Declaration are subject to the Shari'ah [22], the only source of reference for explanation or clarification of any of its Articles[23], This Declaration attracted much criticism due to the superfluous dominance of Islamic religious tenets in limiting the enjoyment of human rights.

Considering the widespread criticisms on the Cairo Declaration, League of Arab States adopted a modified Arab Charter on Human Rights in 1994 [24]. It was also widely criticized by many human rights organizations both within and beyond the region as failing to meet international human rights standards. This has resulted into the adoption of a new ArabCharter on Human Rights in 2004 [25]. Article 5 of the Charter guarantees the right to Life. Article 8 prohibits torture or cruel, inhuman or degrading treatment or punishment. Article 14 guarantees right to liberty and security of person and prohibit any person to be arrested, searched or detained without a legal warrant and anyone who is arrested shall be informed of the reasons for his arrest at the time of arrest in a language understood by the arrested person and shall be promptly informed of any charges against him. Anyone who is arrested has a right to contact his relatives and shall be produced before a judge within a reasonable time. Anyone who is the victim of unlawful arrest or detention shall be entitled to compensation.

Thus, the Arab Charter provides safeguards and 
procedural guarantees in the event of deprivation of liberty such as the right to be informed of the grounds of arrest, right to know the charges and right to be produced before a court. It also guarantees a right to claim compensation, if anyone is aggrieved by unlawful arrest or detention. The Charter provides for the constitution of an Arab Committee on Human Rights for the effective protection of human rights. Unfortunately, it has not been constituted so far.

In fact, the Charter of 2004 also suffers the same way the earlier Charter and Cairo Declaration suffered due to superfluous intrusion of Shari'ah. This is evident from preamble of the 2004 Charter which acknowledges the eternal principles of brotherhood established by the Shari'ah and other divinely revealed religions and expresses belief in the rule of law and reaffirms the principals of the U.N. Charter with the international Bill of Human Rights, together with the Cairo Declaration. The Arab human rights documents appears to be more of cultural than of universal due to the religious subjugation of human rights. However, it provides for the protection of persons from arbitrary arrest, illegal detention, torture, etc. But the main criticism connected with the 2004 Charter is that it does not provide any effective mechanism for the enforcement of rights guaranteed in the Charter [26]. No serious measures have been taken to constitute Arab Committee on Human Rights for the effective protection of rights under the Charter. So, from the enforceability point of view also the Arab regional system must be considered as highly immature.

\section{ASIAN REGIONAL SYSTEM}

Probably Asia is the only continent which does not have a regional human rights system like that of European, InterAmerican or African systems for the redressal of grievances against violation of human rights. The reason for not having a unified system for Asia might be due to its geographical vastness and cultural, economical, religious and social diversities. However, there were attempts to create a separate system for Asia. As a result, "The Association of Asian Parliament for Peace" (AAPP) was established in September 1999 in Dhaka, Bangladeshas a collective effort of a group of a parliamentarians and members of civil society in Asia for promoting peace, democracy and human rights in the Asian region. The AAPP has been converted into Asian Parliamentary Assembly (APA) in 2006 broadening the areas of co-operation towards regional integration. The APA consisted of forty one Member nations and eighteen observers in 2007. India is a member of APA.

In fact, there were attempts to have a Charter of Human Rights for Asia. Through the efforts of a Non-Governmental Agency named Asian Human Rights Commission along with other working groups drafted an Asian Charter of Human Rights in 1997 [27]. The AAPP has also made a draft Charter but it attracted much criticism because AAPP itself has clothed with the authority for supervision, monitor and enforceability. In sum, none of these attempts have been successful and the Charter of Human Rights for Asian region remains still a dream. It is not an easy task to formulate a unified regional Charter for Asia due to the vast diversities that exist in the continent and in many countries in Asia.
However, the argument of cultural, religious, ideological or linguistic diversities cannot be a sound ground for not having a human rights institution for the protection of human rights generally and from the police particularly.

\section{CONCLUSION}

There exist different regional systems for the protection of human rights, some of which are effective while some are not. Among the regional systems, European system can be considered as very successful one. Its success is due to the efficient mechanism for the redressal of grievances by the individuals through the ECtHR directly and effective monitoring by the CoM that the member states implements the decision of the ECtHR. The Inter-American regional system is more complex than the European regional system. Unlike European system, an individual or group cannot approach directly to the Court. The issue must come to the Court through the American Human Rights Commission. There is no enforcement procedure in the American system and decisions are not necessarily accepted as legally bindings. The African system, though not fully functional, has been trying to follow the footsteps of the Europe system. In the African regional system the only enforceable mechanism available is through the African Commission. However, due to diverse political situations that exist among the Member Nations within the Union makes it more complex for the monitoring and remedial mechanisms in this system. Further, the Member Nations are not as transparent and responsible as the Member Nations of CoE. This adversely influences people not to bring cases of violation before the Commission. Even when a case is brought and decision is rendered, there is no efficient mechanism for monitoring that the decision is properly complied with by the Member State.

The Minsk Convention and the Arab Charter provide elaborate provisions for the protection of human rights from the police, but there is no effective mechanism to enforce the rights in the event of its violation. Further, the2004 Arab Charter provides human rights and freedoms within the four walls of Islam and Shari'ah due to which there is wide criticism about the human rights protection under the Arab Charter. Though the Minsk Convention and Arab Charter are not functional, at least they are in existence, while the Asian Charter is not even in existence even after repeated attempts. Thus, the scenario of regional countries' systems for the protection of human rights from the police is diverse in its scope, application, effectiveness and enforceability.

\section{REFERENCES}

[1] The Committee of Ministers is the main decision-making body of the $\mathrm{CoE}$ and is composed of the Foreign Affairs Ministers of all Member States.

[2] European Convention on Human Rights, Art. 50.

[3] The European Convention for the Prevention of Torture was adopted in 1987 and came into force in 1989.

[4] European Convention for the Prevention of Torture, Art. 1.

[5] European Convention for the Prevention of Torture, Art. 4

[6] European Convention for the Prevention of Torture, Art. Art. 8 (3) $\&(4)$.

[7] The Organization of American States originated in the International Union of American Republics in 1890, but was established in its modern form at the 1948 Bogota conference. 
[8] There are 35 Organization of American Member States, 25 having ratified the convention and 20 having recognized the jurisdiction of the Court established under the Convention

[9] American Convention on Human Rights, Art. 57.

[10] American Convention on Human Rights, Art. 63(1).

[11] Inter-American Convention on the Forced Disappearance of Persons, Art. V, VII - XI

[12] African Charter on Human and Peoples' Rights, Art. 30.

[13] African Charter on Human and Peoples' Rights, Art. 45.

[14] Commonwealth of Independent States Convention on Human Rights and Fundamental Freedoms, Art. 2.

[15] Commonwealth of Independent States Convention on Human Rights and Fundamental Freedoms, Art. 4.

[16] Commonwealth of Independent States Convention on Human Rights and Fundamental Freedoms, Art. 5

[17] Commonwealth of Independent States Convention on Human Rights and Fundamental Freedoms, Art. 5(2).

[18] Muslim Personal Law.

[19] Cairo Declaration of the Human Rights, Art. 24.

[20] M. Rishmawi, "The Revised Arab Charter on Human Rights: A Step Forward," Human Rights Law Review, vol. 5, pp. 368, 2005.

[21] M. Rishmawi, "The Arab Charter on Human Rights and the League of Arab States: An Update," Human Rights Law Review, Oxford University Press, vol. 10, pp. 170, 2010.

[22] Cairo Declaration of the Human Rights, Art. 24.

[23] F. D. Varennes, Asia-Pacific Human Rights Documents and Resources, $1^{\text {st }}$ Ed, MartinusNijhoff Publishers, vol. 1, pp. 133, 1998.

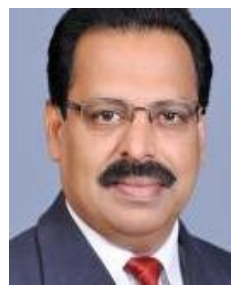

H. Abdul Azeez is a Indian national, he has taken his Ph.D. in Law from the University of Kerala, India with Junior Research Fellowship awarded by University Grants Commission of India. He took his Second LL.M.from Central European University, Hungary, Europe in 2008in comparative constitutional lawwith full fellowship and the first LL.M from University of Kerala in Constitutional Law in 1991. He took his LL.B. and BSc. (Hons.) in Chemistry from Aligarh Muslim University, India in 1984 and 1988 respectively. He is currently working as the Head of Department (Law) at the KeralaPolice Academy, Thrissur, India. Earlier, he worked as Judicial Magistrate,Advocate, and Assistant professor of LawinIndia. $\mathrm{He}$ has experience as Associate Professor of Law in Africa, Research Assistant in Redress Trust, London and Legal Advisor in Children's Rights Alliance for England, London. He has attendedsummer training on "Teaching Law, Human Rights and Ethics" with full fellowship conducted by Columbia University, U.S.A. and Public Interest Law Institute, Budapest, Hungary. He is the author of 'Jurisprudence', (Talent Publications, India, 2003). His book on 'Protection of Human Rights from the Police- the Legal Imperatives', (Pioneer Publications,Agra, India, 2012) is in the press. His Article 'Cloning, Ijthihad and Islamic Jurisprudence' is published in Mindanao Legal Journal, Philippines (2012). Dr. Azeezalso worked as Consulting Editor of Kerala Criminal Cases Law Journal and Panel Writer of Kerala State Women's Commission, India. His research interests are human rights management and the police, freedom from the religion, and good governance and the development. 